\title{
Огнева Н.И. \\ Конституция Российской Федерации и система функций современ-ного Российского государства
}

Государственный социально-гуманитарный университет (Россия, Коломна)

doi: $10.18411 / g d s n-25-12-2017-22$

idsp: 000001:gdsn-25-12-2017-22

Методология системных исследований занимает устойчивые позиции и в теоретико-правовой науке $[2 ; 3 ; 11 ; 13 ; 14 ; 15]$, позволяя получать относительно целостную картину государства и права как сложноорганизованных систем, выявлять и объяснять внутренние и внешние связи между ними и их компонентами. В современной теории государства и права сложно выделить проблему, по отношению к которой использование системного метода не обеспечивало бы приращения знания. В полной мере это относится к функциям государства, познание которых в отрыве от системного анализа становится трудноразрешимой задачей и малосодержательным процессом.

Особое значение проблематика системности функций государства приобретает в современных условиях, характеризующихся противоречивостью и непрерывным усложнением социальных связей, изменением социальной роли государства. Стоит признать, что, несмотря на увеличение объема социального саморегулирования, государство - единственный социальный институт, способный принять на себя основную нагрузку и ответственность по реализации проектов системного социального переустройства. Функции государства при этом выступают главной формой воплощения государственно-властной энергии, в связи с чем, их концептуальный, в том числе системный, анализ представляется не простой, но необходимой научно-практической задачей.

«При модернизации государственных институтов, - отмечает Ю.А. Тихомиров, следовало бы учитывать две главные исходные позиции. Первая - концепции развития государства, его цели, функции и задачи в разных сферах общественной жизни. Вторая системность организационно-функциональных изменений, их связи как элементов структуры государства. Без этого намечаемые перемены будут иметь частный и локальный характер, как впрочем, нередко и бывает» [16, с.12].

Вполне очевидно, что целостная социальная система представляет собой единственно возможную форму существования и функционирования государства [17, c.16], как внутри общества при обеспечении целостности и функциональности основных компонентов-подсистем (экономика, культура, экология, политика и др.), так и на глобальном уровне при участии в обеспечении международной интеграции и мирового порядка [6, с.3-4].

Данное обстоятельство порождает предварительное суждение о том, что системные свойства созидательной и охранительной функций являются воплощением аналогичных свойств государства и также имеют внешние и внутренние формы проявления. Другими словами, системность одновременно выступает дифференцирующим (морфологическим) началом, обусловливающим анализ структуры и внутренних связей между элементами охранительной функции государства и интегрирующим принципом, выражающимся в способности обеспечивать целостность и устойчивость государства - системы более высокого порядка.

Не имея возможности охватить все функции государства в рамках настоящей статьи, остановимся на созидательной и охранительной функциях, имманентных государству, которые осуществляются им на каждом историческом этапе развития и в силу указанных характеристик выступают носителями системных свойств.

Системность функций государства проявляется в том, что им присущи внутренняя связь и взаимообусловленность. Данная связь обусловлена постоянным усложнением 
государственного развития, неуклонным возрастанием объема решаемых государством задач. Сегодня вряд ли можно представить реализацию конкретной функции государства как процесс изолированной деятельности государства или отдельных его органов [4, c.222].

Ocобое значение вопросы системности функций государства приобретают в условиях глобализации. «Государство в процессе осуществления своих функций, указывает М.Н. Марченко, - подвергаясь воздействию со стороны глобальных факторов, вовсе не является по отношению к ним, как и ко всему процессу глобализации в целом, пассивной стороной» [10, с.41].

Внешняя среда существования и развития государства оказывает все более заметное воздействие на систему его функций, на каждую в отдельности, в том числе и на рассматриваемые в статье [6, с.41]. Каждая из анализируемых функций выступает элементом системы функций государства и, будучи включенной в нее, находится в определенных связях и отношениях с иными функциями, обеспечивая целостность, развитие и функционирование государства и общества. Осуществляемые на любом историческом этапе, обеспечивающие безопасность, целостность и непрерывное развитие общества охранительная и созидательная функции образуют диалектическое единство.

Положение о наличии теснейшей связи между государством и правом сегодня имеет аксиоматичное значение. Данная связь обладает генетическим характером и множеством форм проявления, главными из которых можно считать закрепление в праве структуры государства, связей между ее элементам, а также основ его функционирования $[12$, c.67].

Принимая во внимание точку зрения Л.Б. Тиуновой, справедливо полагающей, что «структура конституции как бы накладывается на государство, интегрируя его как особую систему» [15, с.118], считаем обоснованным суждение о том, что нормативный правовой акт, обладающий высшей юридической силой, должен содержать положения о функциях государства, их системе.

В этом смысле весьма продуктивен сравнительный анализ Конституции СССР 1977 г. [8] и Конституции Российской Федерации 1993 г. [7], который в контексте настоящей проблемы обнаруживает не только общее и особенное, но также позволяет судить о некоторых преимуществах последней советской Конституции. Несмотря на критические оценки $[5$, с.35; 18, с.62], в целом Конституцию СССР следует признать вполне удачным документом [1, с.6; 9, с.3-6]. В преамбуле и разд. 1 Конституции СССР 1977 г. содержатся положения, свидетельствующие о важности охранительной и созидательной функций, подчеркивающие их взаимодополняющий, т.е. системный, характер и служащие идеолого-правовой основой их реализации. Приведем некоторые из них: «Продолжая свою созидательную деятельность...» (преамбула); «Советское государство - орудие защиты революционных завоеваний, строительства социализма и коммунизма»; «полнее раскрываются созидательныле силы нового строя»; «Государство охраняет социалистическую собственность и создает условия для ее преумножения»; «В интересах поколений в СССР принимаются необходимые меры для охраны и использования земли и ее недр, водных ресурсов, растительного и животного мира, для сохранения в чистоте воздуха и воды, обеспечения воспроизводства природных богатств и улучшения окружающей человека среды»; «Государство заботится об охране, преумножении и широком использовании духовных ценностей».

Несомненным технико-юридическим достоинством Конституции СССР 1977 г. стоит признать четко и недвусмысленно закрепленную систему и иерархию целей, задач и функций государства.

В преамбуле Конституции СССР 1977 г. декларировалось: «Высшая цель Советского государства - построение бесклассового коммунистического общества, в котором получит развитие общественное коммунистическое самоуправление». Были закреплены также задачи, достижение которых являлось необходимым условием 
реализации высшей цели. Достаточно четкое закрепление получили цели Советского государства, определявшие систему и содержание его функций в соответствующих сферах жизнедеятельности общества.

При выявлении конституционных основ системности функций современного Российского государства первоочередное внимание нужно уделить анализу содержания преамбулы и гл. 1 Конституции 1993 г. В данном случае приходится основываться на приемах герменевтики, поскольку понятия «функция государства», «цель государства» в тексте действующей Конституции не употребляются.

В положении, объявляющем многонациональный народ единственным источником власти (ч. 1 ст. 3), и его проекции на декларацию о стремлении к процветанию и благополучию страны и сохранении исторически сложившегося государственного единства просматриваются конституционные основы реализации созидательной и охранительной функций государства, получающих детализацию и конкретизацию в иных конституционных нормах.

В гл. 1 закреплены положения, конкретизирующие и детализирующие содержание и структурную организацию имманентных функций Российского государства. Так, ст. 2 объявляет человека и его права высшей ценностью и обязывает государство признавать, соблюдать и защищать права и свободы человека и гражданина. В ст. 18 содержится детализирующее положение, наделяющее права и свободы характером ценностносмыслового ориентира правовой политики и деятельности всех звеньев механизма государства.

Относительно иных положений гл. 1 Конституции Российской Федерации, в системе составляющих конституционно-правовую основу реализации охранительной функции и цементирующих ее комплексность и структурность, необходимо отметить следующие: охрана государственной власти (ч. 4 ст. 3); охрана суверенитета, в том числе территориальной целостности и неприкосновенности (ч. 3 ст. 4); охрана труда и здоровья, социальная защита (ст. 7); охрана собственности (ч. 2 ст. 8); охрана земли и иных природных ресурсов (ч. 1 ст. 9).

Некоторые конституционные положения следует рассматривать в качестве основы реализации созидательной функции государства. К таковым следует отнести: создание условий, обеспечивающих достойную жизнь и свободное развитие человека (ч. 1 ст. 7); установление гарантированного минимального размера оплаты труда; государственную социальную поддержку, развития социальных служб (ч. 2 ст. 7); обеспечение единого экономического пространства, поддержка конкуренции и предпринимательства (ч. 1 ст. 8).

В заключение отметим, что, говоря о конституционных основах созидательной и охранительной функций, нельзя игнорировать то обстоятельство, что их разграничение в зависимости от того, к какой функции они «ближе», весьма условно. Нередко имеет место совпадение сфер и объектов у двух рассматриваемых функций, что в свою очередь означает известное совпадение и правовых основ их реализации. В целом же системное видение проблематики функций государства, является предпосылкой формирования целостной концепции социально-политических преобразований, направленных на повышение качества жизни граждан России и укрепление целостности российской государственности.

$$
\text { *** }
$$

1. Автономов А.С. Ценность Конституции // Государство и право. 2009. № 3.

2. Алексеев С.С. Структура советского права. М., 1975.

3. Бабаев В.К. Советское право как логическая система. М., 1978.

4. Байтин М.И. Сущность и основные функции социалистического государства. Саратов, 1979.

5. Дмитриев Ю.А. О юридическом значении преамбулы Конституции России // Государство и право. 2008. № 12 .

6. Киреева С.А. Межгосударственная интеграция как внешняя функция Российского государства. Автореф. дисс. ... докт. юрид. наук. Саратов, 2006. 
7. Конституция Российской Федерации (принята на всенародном голосовании 12 декабря 1993 г.) (с поправками) // Российская газета. 1993. 25 декабря. № 237.

8. Конституция (Основной закон) Союза Советских Социалистических Республик (принята на внеочередной седьмой сессии Верховного Совета СССР девятого созыва 7 октября 1977 г.) // Ведомости Съезда народных депутатов СССР и Верховного Совета СССР. 1977. № 41. С. 617.

9. Кутафин О.Е. Современное состояние и перспективы развития науки конституционного права Российской Федерации // Государство и право на рубеже веков. Конституционное и административное право. М., 2000.

10. Марченко М.Н. Государство и право в условиях глобализации. М., 2011.

11. Матузов Н.И. Правовая система и личность. Саратов, 1987.

12. Неновски Н. Единство и взаимодействие государства и права. М., 1982.

13. Синюков В.Н. Российская правовая система. Введение в общую теорию. М., 2010.

14. Сорокин В.В. Концепция эволюционного преобразования правовых систем в переходный период. Барнаул, 2002.

15. Тиунова Л.Б. Системные связи правовой действительности: Методология и теория. СПб., 1991.

16. Тихомиров Ю.А. О модернизации государства // Журнал российского права. 2004. № 4.

17. Чинчиков А.А. Целостность государства: вопросы теории. Дисс. ... докт. юрид. наук. М., 1995.

18. Шейнис В.Л. Тернистый путь Российской Конституции // Государство и право. 1997. № 12. 